\title{
Respon pertumbuhan dan produksi tanaman kedelai (Glycine max L.) pada berbagai dosis dan jenis pupuk organik
}

\author{
(Response of growth and yield of soybean (Glycine max L.) on dosages and kinds of organic \\ fertilizers)
}

\author{
N. Zahrotun, Yafizham dan E. Fuskhah \\ Agroecotechnology, Faculty of Animal and Agricultural Sciences, Diponegoro University \\ Tembalang Campus, Semarang 50275 - Indonesia \\ CorrespondingE-mail:nurzahra140195@gmail.com
}

\begin{abstract}
ABSTRAK
Penelitian bertujuan untuk mengkaji pengaruh interaksi antara dosis dan berbagai jenis pupuk organik terhadap pertumbuhan dan produksi tanaman kedelai. Penelitian telah dilaksanakan pada bulan Mei - Agustus 2017 di Lahan Percobaan dan Laboratorium Ekologi dan Produksi Tanaman, Fakultas Peternakan dan Pertanian, Universitas Diponegoro, Semarang. Penelitian menggunakan Rancangan Acak Lengkap (RAL) Faktorial 2 x 5 dengan 3 ulangan. Faktor pertama adalah dosis pupuk yaitu $\mathrm{D}_{1}: 50 \mathrm{~kg} \mathrm{P} /$ ha dan $\mathrm{D}_{2}: 100 \mathrm{~kg}$ P/ha. Faktor kedua adalah jenis pupuk yaitu $\mathrm{J}_{0}: \mathrm{SP}-36, \mathrm{~J}_{1}$ : bioslurry, $\mathrm{J}_{2}$ : kotoran sapi, $\mathrm{J}_{3}$ : kotoran kambing dan $\mathrm{J}_{4}$ : kotoran ayam. Parameter yang diamati adalah tinggi tanaman, jumlah daun, jumlah polong total dan bobot 100 biji. Data dianalisis menggunakan analisis ragam dan apabila terdapat pengaruh nyata dilanjutkan dengan Uji Duncan Multiple Range Test (DMRT) taraf 5\%. Hasil penelitian menunjukkan bahwa jenis pupuk kotoran kambing mampu meningkatkan pertumbuhan dan produksi tanaman kedelai paling tinggi dibandingkan dengan pupuk kotoran ayam, kotoran sapi, bioslurry dan SP36 dengan dosis pupuk $50 \mathrm{~kg}$ P/ha.

Kata kunci : kedelai, pupuk organik, pupuk SP-36.
\end{abstract}

\begin{abstract}
The research aimed was to study the interaction between dosages and kinds of organic fertilizer on growth and yield of soybean. The research was conducted in May - August 2017 at Experimental Field and Ecology and Plant Production Laboratory, Faculty of Animal and Agriculture, Diponegoro University, Semarang. The research design used completely randomized design with factorial design $2 \mathrm{x}$ 5 with 3 replications. The first factor were organic fertilizer dosages $\mathrm{D}_{1}: 50 \mathrm{~kg} \mathrm{P} / \mathrm{ha}$ and $\mathrm{D}_{2}: 100 \mathrm{~kg}$ $\mathrm{P} /$ ha. The second factors were kind of organic fertilizers J0 : SP-36, $\mathrm{J}_{1}:$ bioslurry, $\mathrm{J}_{2}:$ cow manure, $\mathrm{J}_{3}$ : goat manure, and $\mathrm{J}_{4}$ : chicken manure. The parameters observed were plant height, number of leaves, total number of pod, and 100 seeds weight. Data analyzed using analysis of variance and using Duncan Multiple Ranged Test on alpha 5\%. The result showed that the goat manure fertilizer can increase the growth and production of soybean plant is highest compared with chicken manure, cow manure, bioslurry and SP-36 with dosage of $50 \mathrm{~kg} \mathrm{P} / \mathrm{ha}$.

Keywords : soybean, organic fertilizer, fertilizer SP-36.
\end{abstract}

\section{PENDAHULUAN}

Kedelai adalah salah satu tanaman polongpolongan dan merupakan sumber utama protein, minyak nabati dan tanaman pangan utama terpenting setelah padi dan jagung. Menurut Pusat Data dan Sistem Informasi Pertanian, Kementerian Pertanian (2016), produksi kedelai dalam negeri baru mencapai 920 ribu ton/tahun. Pemenuhan kebutuhan kedelai sebanyak 67,99\% 
harus diimport dari luar negeri, hal ini terjadi karena produksi dalam negeri tidak mampu mencukupi permintaan produsen tahu dan tempe. Menurut Pakaya dkk. (2012), kedelai varietas Grobogan merupakan kedelai unggul nasional karena memiliki potensi rata-rata produksi mencapai 2,6 ton/ha. Kedelai varietas Grobogan termasuk jenis varietas genjah yang mempunyai keunggulan umur lebih pendek dan ukuran polong besar (Prasetyo dkk., 2014). Produksi tanaman kedelai sangat dipengaruhi oleh teknik budidaya, pengendalian hama dan pemupukan. Pemupukan merupakan salah satu cara untuk memenuhi kebutuhan akan unsur hara dalam jumlah yang seimbang untuk menunjang pertumbuhan vegetatif dan generatif (Anindyawati, 2010).

Pemupukan ditingkat petani sangat bervariasi. Petani masih banyak menggunakan pupuk anorganik dan tidak memperhatikan dosis serta digunakan secara terus menerus. Penggunaan pupuk anorganik berdampak positif terhadap peningkatan produksi dan kualitas panen, namun pupuk anorganik mempunyai dampak negatif, seperti kondisi tanah menjadi cepat mengeras dan kurang menyimpan banyak air. Jika digunakan secara terus menerus penggunakan dosis pupuk anorganik yang berlebihan akan menyebabkan pertumbuhan tanaman tidak optimal.

Salah satu upaya yang dapat dilakukan untuk meningkatkan produksi tanaman kedelai yaitu dengan memperbaiki teknik budidaya seperti penggunaan pupuk organik. Pupuk organik merupakan hasil dekomposisi bahan-bahan organik yang diurai oleh mikroba, yang hasil akhirnya dapat menyediakan unsur hara yang dibutuhkan tanaman. Tanaman akan tumbuh dengan baik dan subur apabila unsur hara yang dibutuhkan tersedia dengan cukup dan seimbang serta pembentukan pucuk atau daun baru akan lebih baik dengan tersedianya nutrisi bagi tanaman (Dewi, 2016). Penambahan bahan organik seperti kotoran sapi, ayam dan kambing merupakan langkah penting dalam memperbaiki kesuburan tanah, setiap kotoran ternak yang berbeda memiliki kandungan unsur hara yang berbeda (Latuamury, 2015). Unsur hara yang paling dibutuhkan tanaman dalam jumlah yang banyak dan berimbang adalah unsur nitrogen, fosfor, dan kalium. Unsur hara nitrogen berperan merangsang pertumbuhan daun, cabang dan pembentukan klorofil. Fosfor dan kalium berperan dalam merangsang perkembangan akar, mempercepat pembungaan dan pemasakan biji (Supartha dkk., 2012).

Penelitian ini bertujuanuntuk mengkaji pengaruh interaksi antara berbagai dosis dan jenis pupuk organik terhadap pertumbuhan dan produksi tanaman kedelai.

\section{MATERI DAN METODE}

\section{Materi}

Penelitian dilaksanakan pada bulan Mei Agustus 2017 di Lahan Percobaan dan Laboratorium Ekologi dan Produksi Tanaman Fakultas Peternakan dan Pertanian Universitas Diponegoro, Semarang. Bahan-bahan yang digunakan adalah benih kedelai varietas Grobogan, pupuk anorganik SP-36 $\left(36 \% \mathrm{P}_{2} \mathrm{O}_{5}\right)$,

Tabel 1. Rata-rata Tinggi Tanaman Kedelai yang diberi Dosis dan Jenis Pupuk yang Berbeda.

\begin{tabular}{lccc}
\hline \hline \multirow{2}{*}{ Perlakuan Jenis Pupuk } & \multicolumn{2}{c}{ Dosis Pupuk $\mathrm{P}_{2} \mathrm{O}_{5}(\mathrm{~kg} / \mathrm{ha})$} & \multirow{2}{*}{ Rerata } \\
\cline { 2 - 3 } & 50 & 100 & \\
\hline \multirow{3}{*}{ Sp-36 } & 24,45 & 21,75 & 23,10 \\
Bio-slurry & 22,27 & 22,67 & 22,47 \\
Kotoran Sapi & 20,63 & 18,52 & 19,57 \\
Kotoran Kambing & 24,69 & 21,49 & 23,09 \\
Kotoran Ayam & 24,10 & 19,75 & 21,92 \\
$\quad$ Rerata & $23,23^{\mathrm{a}}$ & $20,83^{\mathrm{b}}$ & \\
\hline
\end{tabular}

Superskrip yang berbeda pada baris rerata menunjukkan berbeda nyata pada taraf $5 \%(\mathrm{P}<0,05)$. 
pupuk bioslurry, pupuk kotoran sapi, pupuk kotoran kambing dan pupuk kotoran ayam, air, dan media tanam. Alat yang digunakan adalah pot, meteran, cangkul, gembor, timbangan, alat tulis dan kamera.

\section{Metode}

Penelitian ini dimulai dari tahap persiapan penelitian yaitu menyiapkan bahan dan alat yang akan gunakan dalam penelitian seperti benih kedelai varietas Grobogan, pupuk SP-36 dan pupuk bioslurry, pupuk kotoran sapi, kotoran ayam dan kotoran kambing dan media tanam yang diambil dari Fakultas Peternakan dan Pertanian Universitas Diponegoro, Semarang. Pelaksanaan dilakukan dengan memilihan benih kedelai varietas Grobogan, pengisian media tanah dalam pot, media tanam diberikan pupuk kandang sesuai dengan perlakuan pupuk yaitu pupuk SP-36, pupuk bioslurry, pupuk kotoran sapi, pupuk kotoran kambing, pupuk kotoran ayam dan dosis pupuk $50 \mathrm{~kg} \mathrm{P} / \mathrm{ha}$ dan $100 \mathrm{~kg}$ P/ha. Penanaman benih kedelai dilakukan satu minggu setelah pupuk organik diberikan pada media tanam. pestisida hayati. Pengambilan data pertumbuhan dilakukan setiap minggu, sedangkan untuk parameter perkembangan dilakukan setelah tanaman kedelai dipanen. Parameter yang diamati adalah tinggi tanaman, jumlah daun, jumlah polong total dan bobot 100 biji.

\section{Rancangan Percobaan dan Analisis Data}

Penelitian dilakukan dengan model RAL (Rancangan Acak Lengkap) Faktorial 2x5 dengan 3 ulangan. Faktor pertama adalah dosis pupuk yang terdiri dari dua taraf yaitu $D_{1}: 50 \mathrm{~kg} \mathrm{P} / \mathrm{ha}$ dan $\mathrm{D}_{2}: 100 \mathrm{~kg}$ P/ha. Faktor kedua adalah jenis pupuk yaitu $\mathrm{J}_{0}$ : SP-36, $\mathrm{J}_{1}$ : pupuk bioslurry, $\mathrm{J}_{2}$ : pupuk kotoran sapi, $\mathrm{J}_{3}$ : pupuk kotoran kambing, $\mathrm{J}_{4}$ : pupuk kotoran ayam. Analisis data dilakukan secara statistik dengan prosedur sidik ragam (uji F) pada taraf $5 \%$. Apabila ada pengaruh terhadap perlakuan maka dilanjutkan dengan uji lanjut perbandingan antar perlakuan dengan menggunakan uji DMRT (Duncan's Multiple Range Test) pada taraf 5\%.

\section{HASIL DAN PEMBAHASAN}

Tabel 2. Rata-rata Jumlah Daun Tanaman Kedelai yang diberi Dosis dan Jenis Pupuk yang Berbeda.

\begin{tabular}{lccc}
\hline \hline \multirow{2}{*}{ Perlakuan Jenis Pupuk } & \multicolumn{2}{c}{ Dosis Pupuk $\mathrm{P}_{2} \mathrm{O}_{5}(\mathrm{~kg} / \mathrm{ha})$} & \multirow{2}{*}{ Rerata } \\
\cline { 2 - 3 } & 50 & 100 & \\
\cline { 2 - 3 } Sp-36 & --06 & 4,21 & 4,14 \\
Bio-slurry & 5,06 & 4,75 \\
Kotoran Sapi & 5,02 & 4,48 & 4,48 \\
Kotoran Kambing & 4,69 & 5,06 & 5,95 \\
Kotoran Ayam & 4,81 & 7,08 & 5,53 \\
\multicolumn{1}{c}{ Rerata } & 4,90 & 6,17 & \\
\hline
\end{tabular}

Pupuk SP-36 diberikan bersamaan pada saat penanaman benih kedelai. Setiap pot ditanam 2 benih kedelai.

Pemeliharaan tanaman mencakup penyulaman, penyiangan, penyiraman, dan pengendalian hama. Penyulaman dilakukan pada benih kedelai yang tidak tumbuh, penyiraman dilakukan setiap sore hari, penyiangan gulma dilakukan setiap hari. Pengendalian hama dilakukan secara mekanik dan menggunakan

\section{Tinggi Tanaman}

Hasil analisis ragammenunjukkan bahwa dosis pupuk secara sendiri berpengaruh nyata $(\mathrm{P}<0,05)$ pada tinggi tanaman kedelai, sedangkan pada perlakuan jenis pupuk dan interaksi kedua faktor tidak mempengaruhi tinggi tanaman kedelai secara nyata (Tabel 1).

Hasil penelitian menunjukkan bahwa perlakuan dosis pupuk $50 \mathrm{~kg} \mathrm{P} / \mathrm{ha}$ memberikan 
Tabel 3. Rata-rata Jumlah Polong Total Tanaman Kedelai yang diberi Dosis dan Jenis Pupuk yang Berbeda.

\begin{tabular}{|c|c|c|c|}
\hline \multirow{2}{*}{ Perlakuan Jenis Pupuk } & \multicolumn{2}{|c|}{ Dosis Pupuk $\mathrm{P}_{2} \mathrm{O}_{5}(\mathrm{~kg} / \mathrm{ha})$} & \multirow{2}{*}{ Rerata } \\
\hline & 50 & 100 & \\
\hline & \multicolumn{3}{|c|}{ 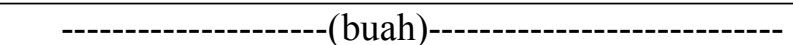 } \\
\hline $\mathrm{Sp}-36$ & 4,33 & 4,50 & $4,42^{\mathrm{d}}$ \\
\hline Bioslurry & 7,17 & 5,50 & $6,08^{c}$ \\
\hline Kotoran Sapi & 7,50 & 7,67 & $7,58^{\mathrm{c}}$ \\
\hline Kotoran Kambing & 14,83 & 17,17 & $16,00^{\mathrm{a}}$ \\
\hline Kotoran Ayam & 13,67 & 13,00 & $13,33^{\mathrm{b}}$ \\
\hline Rerata & 9,50 & 9,37 & \\
\hline
\end{tabular}

Superskrip yang berbeda pada kolom rerata menunjukkan berbeda nyata pada taraf $5 \%(\mathrm{P}<0,05)$.

tinggi tanaman kedelai lebih tinggi dengan ratarata $23,23 \mathrm{~cm}$ dibandingkan dengan pemberian dosis pupuk $100 \mathrm{~kg} \mathrm{P} / \mathrm{ha}$ dengan tinggi tanaman rata-rata $20,83 \mathrm{~cm}$. Hal ini disebabkan pada dosis pupuk $50 \mathrm{~kg} \mathrm{P} / \mathrm{ha}$ yang diberikan pada tanaman sudah mencukupi unsur hara yang dibutuhkan oleh tanaman kedelai untuk pertumbuhannya. Penambahan dosis yang semakin tinggi tidak menjamin tanaman akan tumbuh menjadi baik, apabila pemupukan dilakukan dengan dosis yang lebih tinggi untuk tanaman, maka akan menyebabkan keracunan bagi tanaman atau tanaman tumbuh tidak normal. Hal ini sesuai dengan pendapat Pujiasmanto dkk. (2009) yang menyatakan bahwa pupuk kandang memiliki kandungan unsur yang berbeda-beda, sehingga bila dibedakan dosisnya akan memberikan respon pertumbuhan tanaman yang berbeda, tergantung pada kebutuhan tanaman tersebut akan unsur hara yang terdapat pada masing-masing pupuk kandang. Hal ini didukung oleh pendapat Hikmawati (2015) yang menyatakan bahwa banyaknya pupuk yang dibutuhkan tergantung pada jumlah hara yang dibutuhkan tanaman, pemupukan dengan dosis yang lebih tinggi akan menyebabkan terjadinya keracunan bagi tanaman.

Pertambahan tinggi tanaman diawali dengan bertambahnya pucuk yang semakin panjang dan dilanjutkan dengan perkembanganya menjadi daun dan batang. Pupuk organik seperti pupuk kotoran kambing, ayam, sapi dan bioslurry memiliki kandungan unsur hara yang lengkap karena mengandung unsur hara makro dan mikro meski dalam jumlah yang sedikit. Hal ini sesuai dengan pendapat Anindyawati (2010) yang menyatakan bahwa pemupukan merupakan salah satu cara untuk memenuhi kebutuhan akan unsur hara dalam jumlah yang seimbang untuk

Tabel 4. Rata-rata Bobot 100 Biji Tanaman Kedelai yang diberi Dosis dan Jenis Pupuk yang Berbeda.

\begin{tabular}{|c|c|c|c|}
\hline \multirow{2}{*}{ Perlakuan Jenis Pupuk } & \multicolumn{2}{|c|}{ Dosis Pupuk $\mathrm{P}_{2} \mathrm{O}_{5}(\mathrm{~kg} / \mathrm{ha})$} & \multirow{2}{*}{ Rerata } \\
\hline & 50 & 100 & \\
\hline & \multicolumn{3}{|c|}{ 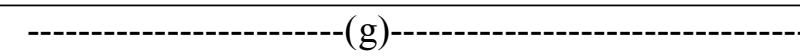 } \\
\hline Sp-36 & 11,14 & 11,58 & $11,36^{\mathrm{c}}$ \\
\hline Bioslurry & 11,69 & 12,46 & $12,07^{\mathrm{b}}$ \\
\hline Kotoran Sapi & 12,71 & 12,59 & $12,65^{\mathrm{b}}$ \\
\hline Kotoran Kambing & 15,86 & 17,99 & $16,92^{\mathrm{a}}$ \\
\hline Kotoran Ayam & 14,13 & 14,24 & $14,18^{\mathrm{a}}$ \\
\hline Rerata & 13,10 & 13,77 & \\
\hline
\end{tabular}

Superskrip yang berbeda pada kolom rerata menunjukkan berbeda nyata pada taraf $5 \%(\mathrm{P}<0,05)$. 
menunjang pertumbuhan vegetatif dan generatif. Hal ini didukung dengan pendapat Roidah (2013) yang menyatakan bahwa kandungan unsur hara dalam pupuk kandang tidak terlalu tinggi. Secara umum, setiap ton pupuk kandang mengandung 5 $\mathrm{kg} \mathrm{N}, 3 \mathrm{~kg} \mathrm{P}_{2} \mathrm{O}_{5}$ dan $5 \mathrm{~kg} \mathrm{~K}_{2} \mathrm{O}$ serta unsur-unsur hara esensial yang lain dalam jumlah yang relatif kecil.

\section{Jumlah Daun}

Hasil analisis ragam menunjukkan bahwa faktor dosis pupuk, jenis pupuk dan interaksi antara keduanya tidak memberikan pengaruh nyata terhadap parameter jumlah daun yang disajikan pada Tabel 2. Jenis pupuk yang diberikan pada tanaman kedelai memberikan hasil yang sama pada jumlah daun. Hal ini menunjukkan bahwa pupuk organik yang diberikan memberikan hasil yang sama pada jumlah daun dibandingkan pada pemberian pupuk anorganik dalam hal ini pupuk SP-36. Hal ini sesuai dengan pendapat Pujiasmanto dkk. (2009) yang menyatakan bahwa jumlah daun merupakan salah satu indikator pertumbuhan yang dapat menjelaskan proses pertumbuhan tanaman. Hal ini sesuai dengan pendapat Purnomo dkk. (2013) yang menyatakan bahwa pertumbuhan adalah proses dalam kehidupan tanaman yang mengakibatkan perubahan ukuran tanaman semakin besar dan juga menentukan hasil tanaman.

Unsur hara makro pada pupuk organik seperti nitrogen $(\mathrm{N})$ memiliki peran penting dalam pertumbuhan daun, kadar unsur hara nitrogen yang banyak akan menghasilkan daun yang lebih banyak dan lebih besar. Daun merupakan salah satu bagian penting dari tanaman, karena adanya kandungan klorofil maka proses fotosintesis dapat berlangsung di daun. Hal ini sependapat dengan Dewanto dkk. (2013) yang menyatakan bahwa unsur hara nitrogen sangat besar kegunaannya bagi tanaman untuk pertumbuhan dan perkembangan. Hal ini didukung oleh pendapat Safei dkk. (2014) yang menyatakan bahwa nitrogen diperlukan tanaman untuk pertumbuhan vegetatif tanaman terutama batang, cabang dan daun. Dewi (2016) menyatakan bahwa tanaman akan tumbuh dengan baik dan subur apabila unsur hara yang dibutuhkan tersedia dengan cukup dan seimbang serta pembentukan pucuk atau daun baru akan lebih baik dengan tersedianya nutrisi bagi tanaman.

\section{Jumlah Polong Total}

Hasil analisis ragam menunjukkan bahwa jenis pupuk secara sendiri berpengaruh nyata $(\mathrm{P}<0,05)$ pada jumlah polong total tanaman kedelai, sedangkan pada perlakuan dosis pupuk dan interaksi kedua faktor tidak mempengaruhi jumlah polong total secara nyata. Uji lanjut DMRT pada Tabel 3., menunjukkan bahwa perlakuan jenis pupuk memberikan perbedaan yang nyata $(\mathrm{P}<0,05)$ terhadap jumlah polong total.

Berdasarkan hasil jumlah polong total tanaman kedelai didapat bahwa pupuk kotoran kambing menghasilkan rata-rata jumlah polong total paling tinggi secara signifikan $(\mathrm{P}<0,05)$ dibandingkan dengan perlakuan pupuk kotoran ayam, kotoran sapi, pupuk bioslurry dan pupuk SP-36. Perlakuan pupuk kotoran sapi memiliki rata-rata jumlah polong total tanaman kedelai yang sama dengan pupuk bioslurry. Pupuk kotoran kambing mengandung unsur hara $\mathrm{K}$ yang lebih tinggi dari pada pupuk kandang lainnya, sedangkan unsur hara $\mathrm{N}$ dan $\mathrm{P}$ hampir sama dengan pupuk kandang lainnya. Hal ini sesuai dengan pendapat Supartha (2012) yang menyatakan bahwa fosfor (P) berperan dalam memperkuat perakaran, mempercepat pembungaan dan pemasakan biji. Kalium (K) berfungsi merangsang perkembangan akar dan bunga. Hal ini didukung oleh pendapat Dinariani dkk. (2014) yang menyatakan bahwa pemberian pupuk kotoran kambing pada saat olah tanah akan terdekomposisi dengan baik, sehingga mudah diserap oleh akar tanaman. Sari dkk. (2015) yang menyatakan bahwa feses kambing mengandung $\mathrm{N}$ dan $\mathrm{K}$ dua kali lebih besar daripada kotoran sapi. Feses kambing mengandung $\mathrm{P}$ lebih tinggi daripada urin kambing.

\section{Bobot 100 Biji}

Hasil analisis ragam menunjukkan bahwa jenis pupuk secara sendiri berpengaruh nyata $(\mathrm{P}<0,05)$ pada bobot 100 biji tanaman kedelai, sedangkan pada perlakuan dosis pupuk dan interaksi kedua faktor tidak mempengaruhi bobot 100 biji secara nyata. Uji lanjut DMRT pada Tabel 4., menunjukkan bahwa perlakuan jenis pupuk memberikan perbedaan yang nyata $(\mathrm{P}<0,05)$ 
terhadap bobot 100 biji.

Berdasarkan Tabel 4 diketahui bahwa pada perlakuan jenis pupuk kotoran kambing, ayam, sapi dan bioslurry berbeda nyata dengan perlakuan pupuk SP-36. Hal ini dikarenakan jenis pupuk organik seperti kotoran kambing, ayam, sapi dan bioslurry memiliki kandungan unsur hara makro dan mikro yang lengkap meski dalam jumlah sedikit, sehingga dapat menunjang kebutuhan unsur hara bagi tanaman dan menghasilkan produksi tanaman kedelai yang meningkat. Pupuk SP-36 hanya mengandung satu unsur hara yang terkandung didalamnya, sehingga kurang mendukung pertumbuhan tanaman yang lainnya. Hal ini sesuai dengan pendapat Arifah (2013) yang menyatakan bahwa penambahan pupuk kandang ke dalam tanah selain menyediakan unsur hara bagi tanaman, dapat meningkatkan jumlah mikroorganisme tanah dan memperbaiki struktur tanah. Hal ini didukung oleh pendapat Subatra (2013) yang menyatakan bahwa pupuk kandang secara bertahap akan terdekomposisi dan unsur hara hasil proses dekomposisi secara bertahap pula akan tersedia bagi tanaman. Dinariani dkk. (2014) menyatakan bahwa pemberian pupuk organik pada saat olah tanah akan terdekomposisi dengan baik, sehingga mudah diserap oleh akar tanaman.

Biji kedelai adalah salah satu indikator produksi pada tanaman kedelai, pemupukan pada tanaman kedelai sangat berpengaruh terhadap hasil produksi, karena dalam pupuk yang diberikan pada tanaman kedelai banyak mengandung unsur hara baik unsur hara makro maupun mikro, terutama adalah kandungan unsur hara phosphor (P). Unsur hara yang terkandung didalam pupuk organik seperti unsur $\mathrm{P}$ bagi tanaman lebih banyak berfungsi untuk mempercepat pembungaan serta pemasakan biji dan buah. Hal ini sesuai dengan pendapat Supartha dkk. (2012) yang menyatakan bahwa unsur hara $\mathrm{P}$ berperan dalam pembelahan sel tanaman, memperkuat perakaran dan mempercepat pembungaan dan pemasakan biji. Hal ini didukung oleh pendapat Hayati dkk. (2012) yang menyatakan bahwa kegunaan pupuk $\mathrm{P}$ adalah mendorong awal pertumbuhan akar, pertumbuhan bunga dan biji, memperbesar persentase terbentuknya bunga menjadi biji.

\section{KESIMPULAN}

Berdasarkan hasil penelitian yang telah dilakukan dapat disimpulkan bahwa jenis pupuk kotoran kambing mampu meningkatkan pertumbuhan dan produksi tanaman kedelai paling tinggi dibandingkan dengan pupuk kotoran ayam, kotoran sapi, bioslurry dan SP-36 dengan dosis masing-masing pupuk $50 \mathrm{~kg} \mathrm{P} / \mathrm{ha}$.

\section{DAFTAR PUSTAKA}

Anindyawati, T. 2010. Potensi selulase dalam mendegradasi lignoselulosa limbah pertanian untuk pupuk organik. Pusat Penelitian Bioteknologi-Lipi Berita Selulosa. 45 (2): $70-77$.

Arifah, S. M. 2013. Aplikasi macam dan dosis pupuk kandang pada tanaman kentang. J. Gamma. 8 (2): 80-85.

Dewanto, F. G., J. J. M. R. Londok dan R. A. V. Tuturoong. 2013. Pengaruh pemupukan anorganik dan organik terhadap produksi tanaman jagung sebagai sumber pakan. J. Zootek. 32 (5) : 1-8.

Dewi, W. W. 2016. Respon dosis pupuk kandang kambing terhadap pertumbuhan dan hasil tanaman mentimun (Cucumis sativus L.) varietas hibrida. J. Viabel Pertanian. 10 (2) : 11-29.

Dinariani., Y. B. S. Heddy dan B. Guritno. 2014. Kajian penambahan pupuk kandang kambing dan kerapatan tanaman yang berbeda pada pertumbuhan dan hasil tanaman jagung manis (Zea mays saccharata sturt). J. Produksi Tanaman. 2 (2): 128-136.

Hayati, M., A. Marliah dan H. Fajri. 2012. Pengaruh varietas dan dosis pupuk SP-36 terhadap pertumbuhan dan hasil tanaman kacang tanah (Arachis hypogaea L. ). J. Agrista. 16 (1) : 7-13.

Hikmawati, M. 2015. Pengaruh dosis pupuk dan penyiangan terhadap produksi kedelai 
(Glycine $\max$ L. Merrill). J. Media Soerjo. $16(1): 158-180$.

Latuamury, N. 2015. Pengaruh tiga jenis pupuk kandang terhadap pertumbuhan dan produksi tanaman kacang hijau (Vigna radiata L.). J. Agroforestri. 10 (2) : 210216.

Pakaya, M. S., W. Pembengo dan F. Zakari. 2012. Respon pertumbuhan dan hasil tanaman kedelai (Glycine max L.) berdasarkan jarak tanam dan pemupukan phonska. J. Penelitian Agronomi. 28 (1): 55-68.

Prasetyo, R. A., A. Nugroho dan J. Moenandir. 2014. Pengaruh sistem olah tanah dan berbagai mulsa organik pada pertumbuhan dan hasil tanaman kedelai (Glycine max L. Merr.) Var. Grobogan. J. Produksi Tanaman. 1 (6) : 486-495.

Pujiasmanto, B., P. Sunu dan A. Imron. 2009. Pengaruh macam mulsa dan dosis pupuk organik terhadap pertumbuhan dan hasil tanaman sambiloto (Andrographis paniculata ness.). J. Ilmu Tanah dan Agroklimatologi. 6 (2): 81-90.

Purnomo, R., M. Santoro dan S. Heddy. 2013. Pengaruh berbagai macam pupuk organik dan anorganik terhadap pertumbuhan dan hasil tanaman mentimun (Cucumis sativus L.). J. Produksi Tanaman. 1 (3): 93-100.
Pusat Data dan Sistem Informasi Pertanian Kementeria Pertanian. 2016. Outlook komoditas pertanian sub sektor tanaman pangan kedelai.

Roidah, I. S. 2013. Manfaat penggunaan pupuk organik untuk kesuburan tanah. J. Universitas Tulungagung Bonorowo.1 (1):30-42.

Safei, M., A. Rahmi dan N. Jannah. 2014. Pengaruh jenis dan dosis pupuk organik terhadap pertumbuhan dan hasil tanaman terung (Solanum melongena L.) varietas mustang F-1. J. Agrifor. 13 (1):29-66.

Sari, D. A., E. Ratnasari dan H. Fitrihidajati. 2015. Limbah ternak kambing etawa sebagai bahan pupuk organik cair untuk budi daya baby corn. J. LenteraBio.4(2) : 143-149.

Subatra, K. 2013. Pengaruh sisa amelioran, pupuk $\mathrm{N}$ dan $\mathrm{P}$ terhadap ketersediaan $\mathrm{N}$, pertumbuhan dan hasil tanaman padi di musim tanam kedua pada tanah gambut. J. Lahan Suboptimal. 2 (2):159-169.

Supartha, I. N. Y., G. Wijana dan G. M. Adnyana. 2012. Aplikasi jenis pupuk organik pada tanaman padi sistem pertanian organik. EJ Agroekoteknologi Tropika. 1 (2) : 98106. 